\title{
Genotype $\times$ environment interaction and kernel yield-stability of groundnut (Arachis hypogaea L.) in Northern Cameroon
}

\author{
Souina Dolinassou, Jean Baptiste Noubissié Tchiagam*, Alain Djiranta Kemoral and Nicolas Njintang Yanou \\ Department of Biological Sciences, Faculty of Science, University of Ngaoundéré, P.O. Box 454, Ngaoundéré, Cameroon.
}

\section{ARTICLE INFO}

Article history:

Received on: 02/12/2015

Revised on: 26/12/2015

Accepted on: 04/01/2016

Available online: 19/02/2016

Key words:

Arachis hypogaea, yield, genotype $\mathrm{x}$ environment interaction, stability analysis, northern Cameroon.

\begin{abstract}
Kernel yield of thirteen groundnut varieties was studied for Genotype by Environment Interaction (GEI) in randomized complete block design with three replications across Pitoa, Gobo and Wakwa (three locations of northern Cameroon) using stability parameters, and Additive Main effects and Multiplicative Interaction analysis (AMMI). The objectives were to estimate the nature and magnitude of GEI, and identify stable high-yielding groundnut cultivars for general adaptation and unstable varieties for specific adaptation. Combined analysis of variance showed significant differences between genotypes, locations and GEI, suggesting differential response of varieties across tested locations, and the need for stability analysis. Differences between genotypes, environments and GEI accounted respectively for $68.91 \%, 16.00 \%$ and $15.08 \%$ of the total variation. Highest kernel yields of $2105,1900,1882,1845$ and $1841 \mathrm{~kg} \mathrm{ha}^{-1}$ were recorded from genotypes Dourou, Blanc, Gobo55-437, Ad-Manipenta and JL 28 respectively. Genotypes NW-Red Esimbi and Ouest-A2 gave the lowest kernel yield of 454 and $1284 \mathrm{~kg} \mathrm{ha}^{-1}$ respectively. Two IPCA of AMMI were significant and captured the largest portion of variation of the total GEI. Stability analysis identified Dourou as the best lines due to its stability and high yield, while Gobo-55-437 and Blanc were specifically adapted to Pitoa and Gobo locations.
\end{abstract}

\section{INTRODUCTION}

Groundnut (Arachis hypogaea L.) is an important oilseed and protein crop produced in tropical and temperate zones on a total surface area of about 24.6 million hectares, and an annual production of approximately 38.2 million tons [1].This annual legume is a native of South America, but is grown throughout the tropical and warm temperate region of the globe between latitudes $40^{\circ} \mathrm{N}$ to $40^{\circ} \mathrm{S}$ [1]. The seeds are a source of protein, vegetable oil, cakes and many industrial products. In Cameroon, groundnut is grown on nearly 380000 ha with an annual production of about $540000 \mathrm{t}$ of kernels [2]. Northern Cameroon accounts for more than $56 \%$ of the national production [2]. Lack of improved high yielding cultivars, low soil fertility, uneven rainfall distribution, incidences of diseases and pests are cited as the major limiting production factors [3]. Within the framework of Peanut Germplasm Project (GGP), varieties mostly from International Crops Research Institute for Semi Arid Tropics (ICRISAT) have been recommended in the three growing areas in the region, considering especially their earliness, the resistance

\footnotetext{
* Corresponding Author

Email: jbnoubissitch@yahoo.fr
}

to major pathogens and the yield [3]. Since 2003, in the absence of seeds distribution structures, farmers have adopted a dozen of cultivars in the Sudano-Sahelian zone of Cameroon [3,4]. Annual production fluctuates due to the sensitive behavior of the genotypes to different environmental conditions [4]. As high yield is one of the main goals of the most plant breeding programs, it is important to upgrade the peanut program by selecting in each of the three growing areas of northern Cameroon, superior cultivars with wide or specific adapation. Although yield traits are governed by a pool of major genes, the best performance of genotypes often depends on environmental conditions $[1,5]$. The adaptability and stability of a variety over diverse environments is usually tested by its degree of interaction with different growing environments $[5,6]$. Failure of genotypes to respond consistently to variable environmental conditions is attributed to Genotype by Environment Interaction (GEI). A genotype is considered to be more adaptive or stable if it has a high mean yield, but with low degree of fluctuation in yielding ability when grown over diverse environments [7]. Knowledge on GEI is advantageous to increase efficiency of breeding program and selection of best genotypes. In meeting the demands for varieties better adapted to varying conditions, the plant breeder is faced with the options of breeding genotypes for either closely defined or wider range of ecologic environment. 
Varietal improvement for stability in yield or adaptation to specific environment should be given appropriate considerations. Peanuts are sensitive to changes under growing conditions; therefore, their yields are very much affected by the environment [7, 8, 9, 10, 11]. In the sudano sahelian zone of Cameroon, GEI analysis in groundnut has not received adequate attention as the crops importance. Limited research has been carried out on its adaptation to various locations.

In Northern region of Cameroon, the yield stability of six groundnut advanced lines was previously evaluated at four locations through regression methods [4].

Different methods have been proposed to solve problems associated to GEI for the determination of genotype adaptation and phenotypic stability of cultivars $[6,12,13,14,15,16]$. These methodologies are usually based on simple or multiple linear regressions, nonlinear regression, multivariate methods and methods that integrate the variance analysis of the principal components analysis $[6,13,14]$.

The major objective of this study was to understand the adaptation of groundnut in northern Cameroon by assessing the effects of genotype, environment and their interaction in terms of seed yield. Responsiveness and yield stability of genotypes to three varying environments were also investigated using stability parameters and AMMI (Main additive effects and multiplicative interaction) analysis.

\section{MATERIALS AND METHODS}

\subsection{Study locations}

After a preliminary trial in 2012 within the Ngaoundéré University campus, field experiments were carried out during 2013 main cropping season, at three locations of Northern Cameroon: Wakwa $\left(7^{\circ} 13^{\prime} \mathrm{N}, 13^{\circ} 34^{\prime} \mathrm{E}\right)$ in the Adamawa region, Pitoa $\left(9^{\circ} 22^{\prime} \mathrm{N}\right.$, $\left.13^{\circ} 31^{\prime} \mathrm{E}\right)$ in the North region and Gobo $\left(10^{\circ} 1^{\prime} \mathrm{N}, 15^{\circ} 24^{\prime} \mathrm{E}\right)$ in the Far North region. These locations are situated within the altitudinal ranges of 300 to $1400 \mathrm{~m}$ at sea level, and represent the varying agro-ecologies of the major groundnut growing areas. Information on planting dates, site designation and environmental variables is contained in Table 1.

\subsection{Plant materials}

Thirteen groundnut pure lines obtained from the Institute of Agricultural Research for Development (IRAD of Maroua, Cameroon) and from Cotton Development Company (SODECOTON) were used in the study. These experimental materials comprised ten conventional groundnut cultivars viz., AdMapienta, Campana, Dourou, Gobo-55-437, CGS 1272, G-M-28206, CGV86003, JL 28, K1332-78 and RMP 91, recommended for cultivation in northern Cameroon [3,17], two elite lines frequently cultivated in the western highlands of Cameroon (NW-Red Esimbi and Ouest-A2), and an exotic variety from ICRISAT (Blanc).

\subsection{Experimental Trial}

In each location, the field experimental design was laid out using randomized complete block design with three replications. Following land preparation, the 13 genotypes were grown in an adjusted density of 90.000 plants ha ${ }^{-1}$. Each plot unit consisted of two rows of $0.5 \mathrm{~m}$ broad x $4 \mathrm{~m}$ length spaced $60 \mathrm{~cm}$ apart. Two seeds of each variety were sown at an intra-row spacing of $40 \mathrm{~cm}$ and thinned to one plant per hill 20 days after sowing (DAS). Normal cultural practices were followed. There was no application of inorganic fertilizers and chemicals throughout the plantings. At maturity, harvesting was done on ten randomly selected plants, when the pods were at maturity. The number of pods per plant during harvesting and the number of kernels per pod were recorded after sun drying. Kernels were later dried in an oven at $60{ }^{\circ} \mathrm{C}$ for about $12 \mathrm{~h}$. The 100 -seed weight was measured by using an electronic balance of $0.001 \mathrm{~g}$ sensitivity (Sartorius Prodilab, France). The kernel yield $\left(\mathrm{kg} \cdot \mathrm{ha}^{-1}\right)$ was evaluated from seed mass, the number of seeds per plant and the plant density (90.000 plants. ha $\left.^{-1}\right)$ [11].

Table 1: Experimental sites, sowing date and mean environmental variables.

\begin{tabular}{cccccccc}
\hline Location & Region & Planting & & \multicolumn{4}{c}{ Environmental variables } \\
& & date & Altitude $(\mathbf{m})$ & Rainfall $(\mathbf{m m})$ & TP $\left({ }^{\circ} \mathbf{C}\right)$ & RH $(\%)$ & Soil type \\
\hline Gobo & Far North & $13^{\text {th }}$ July & 339 & 860 & 27 & 69 & Sandy clay \\
Pitoa & North & $24^{\text {th June }}$ & 476 & 945 & 28 & 66 & Clay loam \\
Wakwa & Adamawa & $22^{\text {nd }}$ April & 1279 & 1539 & 22 & 80 & Silt clay \\
\hline
\end{tabular}

TP: temperature, RH: relative humidity

Table 2: Analysis of variance for kernel yield $\left(\mathrm{kg} \cdot \mathrm{ha}^{-1}\right)$ of 13 groundnut cultivars in three northern Cameroon environments.

\begin{tabular}{cccccc}
\hline Source of variation & df & SS & MS & \% SS & F \\
\hline Genotype (G) & 12 & 6224288.36 & 518690.70 & 68.91 & $14.01^{* *}$ \\
Environment (E) & 2 & 1444150.40 & 722075.20 & 16.00 & $19.50^{* *}$ \\
GEI & 24 & 1361917.23 & 56746.55 & 15.08 & $1.53^{*}$ \\
Residual & 12 & 481158.13 & 40096,51 & & 1.08 \\
Total & 38 & 9030355.85 & & & \\
\hline
\end{tabular}

df: degree of freedom, GEI: genotype by environment interaction, SS: sum of square, MS: Mean square, \% SS: percentage of the sum of square, **: significant at $1 \%$ level of probability; *: significant at $5 \%$ level of probability. 


\subsection{Data analysis}

The combined analysis of variance across locations was done using [5] model with genotypes being considered as fixed effects and replications within environments being random mode in order to evaluate the effect of differences between genotypes, across locations and also to determine whether their interaction was significant. GEI was quantified using pooled analysis of variance, which partitions the total variance into its component parts (genotype, environment, GEI, pooled error). Single analysis of variance was done for the genotypic mean seed yield averaged over environments and its components ie: the number of pods per plant and the 100-seed weight. Least Significant Difference at 5\% level of probability was used for mean separation.

Different stability models were performed: the Finlay and Wilkinson's joint regression analysis (bi) [6], Wricke's ecovalence (Wi) [12], Shukla's procedure of stability $\left(\sigma \mathrm{i}^{2}\right)$ [13], and the AMMI stability value (ASV) described by [18].

The stability analysis by [6] consisted in regressing the performance of a genotype onto an environmental index computed as the mean of all genotypes in an environment. Regression technique was based on the slope of regression line and on the deviation from that slope. A stability parameter was, therefore, a regression coefficient (bi) estimated in the following way [6]:

$$
\mathrm{bi}=\Sigma \mathrm{Y}_{\mathrm{ij}} \mathrm{I}_{\mathrm{j}}-\Sigma \mathrm{I}_{\mathrm{j}}^{2}
$$

where

$\mathrm{Y}_{\mathrm{ij}}$ is the mean performance of genotype $\mathrm{i}$ in $\mathrm{j}^{\text {th }}$ environment, and $\mathrm{Ij}$ is the environmental index obtained as the mean of all genotypes in $\mathrm{j}^{\text {th }}$ environment minus the grand mean.

This parameter can be used for evaluating static stability (bi tends to 0) or dynamic stability (bi tends to 1.0. A genotype with a bi coefficient proximal to unity shows an average response to environmental conditions and this variety is considered adapted to all environments [6]. If the variety has a regression coefficient bi approximating 1.0 and is associated with high mean yield, the variety will show general adaptability. Slopes with bi< 1.0 indicate better adaptation to poor environments, while genotypes with bi $>1.0$ are better adapted to favorable environments [6].

According to [12], the ecovalence (Wi) or stability of the $i^{\text {th }}$ genotype is its interaction with the environments, squared and summed across environments, and expressed as:

$$
\mathrm{Wi}=\Sigma\left(\mathrm{Y}_{\mathrm{ij}}-\mathrm{Y}_{\mathrm{i} .}-\mathrm{Y}_{\mathrm{j}}+\mathrm{Y}\right)^{2}
$$

where

$\mathrm{Y}_{\mathrm{ij}}$ is the mean performance of genotype $\mathrm{i}$ in $\mathrm{j}^{\text {th }}$ environment,

$Y_{i}$ and $Y_{j}$ are respectively the genotype and environment mean, and $\mathrm{Y}$ is the overall mean.

Genotypes with a low Wi value are the must stable [12].

The Shukla's stability variance parameter $\left(\sigma i^{2}\right)[13]$ defined as its variance across environments after the main effects of environmental means have been removed estimated as:

$$
\begin{gathered}
\sigma i^{2}=\left[(\mathrm{g} /(\mathrm{g}-2)(\mathrm{e}-1)] \Sigma \mathrm{i}\left(\mathrm{Y}_{\mathrm{ij}}-\mathrm{Y}_{\mathrm{i} .}-\mathrm{Y}_{\mathrm{j}}+\mathrm{Y}\right)^{2}-\Sigma \mathrm{i} \Sigma \mathrm{j}\left(\mathrm{Y}_{\mathrm{ij}}-\mathrm{Y}_{\mathrm{i} .}-\mathrm{Y}_{\mathrm{j} j}+\right.\right. \\
\mathrm{Y})^{2} /[(\mathrm{g}-1)(\mathrm{g}-2)(\mathrm{e}-1)]
\end{gathered}
$$

where

$\mathrm{g}$ and $\mathrm{e}$ are the number of genotypes and environments respectively,
$Y_{i j}$ is the mean performance of genotype $i$ in $j^{\text {th }}$ environment, $Y_{i}$ and $Y_{j}$ are respectively the genotype and environment mean, and $\mathrm{Y}$ is the overall mean.

A genotype was stable if $\sigma \mathrm{i}^{2}=0$, while a relatively large value of $\sigma \mathrm{i}^{2}$ indicated instability [13].

The AMMI method integrates analysis of variance and principal component analysis into a unified approach [15,19]. The AMMI model first fits additive effects for the main effects of genotypes and environments, using the additive analysis of variance $[15,16]$. Subsequently, the program fits multiplicative effects for GEI by principal components analysis [20]. In order to rank the genotypes, AMMI's stability value (ASV) was calculated using the following formula as suggested by [18]:

$\mathrm{ASV}=[((\mathrm{IPCA} 1$ sum of square $/ \mathrm{IPCA} 2$ sum of square $) \times$ IPCA1 score $\left.)^{2}+(\text { IPCA2 score })^{2}\right]^{1 / 2}$

where,

IPCA1 and IPCA2 are interaction of principal component analysis one and two.

The ASV was the distance from zero in a two dimensional scattergram of Interaction Principal Component Axis 1 (IPCA1) scores against IPCA2 scores [18]. To graphically explain the GEI and adaptation of genotypes to environments, the AMMI biplot between the IPCA1 scores and IPCA2 scores was used. The more IPCA scores approximate to zero, the more stable the genotype over all environments sampled [18]. Genotypes that are close to each other tend to have similar performance and those that are close to environment indicates their specific adaptation [18]. The greater the IPCA scores, either positive or negative, as it is a relative value, the more specifically adapted a genotype is to certain environments [18]. All analyses were performed using the GEST 98 micro-computer program [21].

\section{RESULTS}

\subsection{Analyses of variance}

The combined analysis of variance (Table 3) showed significant differences $(\mathrm{p}<0.05)$ for groundnut cultivars in kernel yield, environments and their interactions. Groundnut seed yields were significantly affected by genotypes which explained $68.91 \%$ of the total variation, while environment and GEI captured respectively $16 \%$ and $15.08 \%$ of the total sum of square. Using AMMI model analysis, the first two Interaction Principal Components Axes (IPCA1 and IPCA2) captured $100 \%$ of the interaction sum of squares. AMMI analysis showed that the first and the second IPCA accounted for $59.45 \%$ and $40.55 \%$ respectively.

\subsection{Variability for kernel yield and components across environments}

The mean yield of genotypes and their components (pods per plant, 100-seed weight), and the environment means are presented in Table 3. The mean kernel yield of varieties across environments ranged from $454.1 \mathrm{~kg} \cdot \mathrm{ha}^{-1}$ for NW-Red Esimbi to $2015.1 \mathrm{~kg} \cdot \mathrm{ha}^{-1}$ for Dourou with the great mean yield of 1557.1 
kg.ha ${ }^{-1}$. The highest mean yield of 2322.1 kg.ha-1 was recorded from line Gobo-55-437 in Gobo and the least $\left(401.8 \mathrm{~kg}^{-\mathrm{ha}^{-1}}\right)$ at the same location for genotype NW-Red Esimbi. The five top ranked lines for kernel yield were Dourou, Blanc, Gobo-55-437, AdMapienta and JL 28, and those showing the lowest seed yield were NW-Red Esimbi, Ouest- $A_{2}$ and CGS 1272. Among locations, the highest yielding environments were Pitoa $\left(1753.1 \mathrm{~kg} \mathrm{ha}^{-1}\right)$ and Gobo-55-437 (1622.6 $\mathrm{kg} \mathrm{ha}^{-1}$ ), whereas the lowest yielding location was Wakwa (1295.6 kg ha $\left.{ }^{-1}\right)$. Genotypes Gobo-55-437 (24), Blanc (22), RMP91 (21.5), Dourou (20.3) and JL28 (19.6) produced the highest number of pods per plant while for 100-seed weight, the best lines were Ad-Manipenta (74.7g), ICGV86003 (54.1g), Campana (53.7g) and Dourou (53.1g).

\subsection{Stability and adaptability of genotypes}

The values of different stability procedures and adaptability measure for the yield of each groundnut genotype are presented in Table 4. The values of bi parameter of [6] ranged from -0.23 (NW-Red Esimbi) to 2.47 (K1332-78). Varieties JL 28, Dourou and NW-Red Esimbi had bi values close to 0 while genotypes K1332-78, Gobo-55-437, GM-28-206 and Blanc showed bi larger than 1.0. Genotypes Campana, Ouest-A2 and ICGV86003 had bi smaller than 1.0, and for CGS1272,
Ad-Mapienta and RMP 91, the regression coefficient bi was close to 1.0. Low values of Shukla's stability variance parameter $\left(\sigma_{i}^{2}\right)$ and Wricke ecovalence (Wi) parameter were recorded for genotypes RMP91; Ouest-A2, JL28, Dourou and ICGV86003, while largest values were noted for genotypes K1332-78, Gobo55-437 and NW-Red Esimbi.

The AMMI stability value (ASV) ranged from 0.68 for genotype JL 28 to 3.12 for line K1332-78. Genotypes JL 28, RMP 91, Dourou, Ad-Mapienta and Campana had lowest ASV values while K1332-78, Gobo-55-437 and GM-28-206 presented the highest values of ASV. No genotype with a stability parameter equal to zero was observed.

\subsection{Biplot analysis}

Figure 1 presents the biplot of the AMMI results for kernel yield. The abscissa shows the first IPCA axis while the ordinate the second IPCA axes. By plotting both the genotypes and environments on the same graph, the associations between genotypes and locations can be seen clearly. RMP 91, Ouest- $\mathrm{A}_{2}$, Dourou, Campana and JL28 are closer to zero. In contrast, Gobo55-437 and K1332-78 were the most divergent with best contribution to GEI. Dourou and Campana appear to have similar interaction with the environments.

Table 3: Mean kernel yield of the 13 groundnut cultivars across three environments in northern Cameroon.

\begin{tabular}{|c|c|c|c|c|c|c|c|}
\hline \multirow{2}{*}{ Genotype } & \multirow{2}{*}{ Code } & \multirow{2}{*}{$\begin{array}{c}\text { Pods } \\
\text { per plant }\end{array}$} & \multirow{2}{*}{$\begin{array}{c}\text { 100-seed } \\
\text { weight }(\mathrm{g})\end{array}$} & \multicolumn{4}{|c|}{ Kernel yield $\left(\mathrm{kg} \mathrm{ha}^{-1}\right)$} \\
\hline & & & & Wakwa $\left(\mathbf{a}_{1}\right)$ & Pitoa $\left(\mathbf{b}_{1}\right)$ & Gobo $\left(c_{1}\right)$ & Genotype mean \\
\hline Ad-Manipenta & 1 & $14.89 \mathrm{~g}$ & $74.78 \mathrm{a}$ & 1485.13 & 1982.20 & 2068.20 & $1845.18 \mathrm{c}$ \\
\hline Blanc & 2 & $22.33 \mathrm{ab}$ & $41.77 \mathrm{~cd}$ & 1587.53 & 2286.53 & 1828.77 & $1900.94 b$ \\
\hline Campana & 3 & $18.56 \mathrm{de}$ & $53.78 \mathrm{~b}$ & 1559.60 & 1730.60 & 1632.87 & $1641.02 \mathrm{~d}$ \\
\hline Dourou & 4 & $20.33 \mathrm{bcd}$ & $53.11 \mathrm{~b}$ & 2053.43 & 2203.70 & 2058.20 & $2105.11 \mathrm{a}$ \\
\hline Gobo-55-437 & 5 & $24.00 \mathrm{a}$ & $39.89 \mathrm{~d}$ & 1187.27 & 2137.80 & 2322.10 & $1882.39 b c$ \\
\hline CGS 1272 & 6 & $17.56 \mathrm{ef}$ & $40.33 \mathrm{~d}$ & 983.47 & 1386.20 & 1576.97 & $1315.54 \mathrm{~g}$ \\
\hline G-M-28-206 & 7 & $18.33 \mathrm{def}$ & $51.11 \mathrm{~b}$ & 1142.57 & 1775.67 & 1859.87 & $1592.70 \mathrm{e}$ \\
\hline ICGV86003 & 8 & $18.11 \mathrm{ef}$ & $54.13 b$ & 1375.53 & 1622.33 & 1378.67 & $1458.84 \mathrm{f}$ \\
\hline JL 28 & 9 & 19.67cde & $51.79 \mathrm{~b}$ & 1764.43 & 1891.57 & 1868.63 & $1841.54 \mathrm{c}$ \\
\hline K1332-78 & 10 & $17.44 \mathrm{f}$ & $43.44 \mathrm{~cd}$ & 913.80 & 2171.23 & 1346.53 & $1477.19 \mathrm{f}$ \\
\hline NW-Red Esimbi & 11 & $6.78 \mathrm{~h}$ & $44.89 \mathrm{c}$ & 526.03 & 434.40 & 401.87 & $454.10 \mathrm{i}$ \\
\hline Ouest-A2 & 12 & $16.78 \mathrm{fg}$ & $42.33 \mathrm{~cd}$ & 1127.37 & 1470.73 & 1255.70 & $1284.60 \mathrm{~h}$ \\
\hline RMP 91 & 13 & $21.56 \mathrm{bc}$ & $51.00 \mathrm{~b}$ & 1136.77 & 1697.37 & 1495.87 & $1443.33 \mathrm{f}$ \\
\hline Environment mean & & 18.18 & 49.41 & 1295.61 & 1753.10 & 1622.63 & 1557.12 \\
\hline
\end{tabular}

For each parameter, the average with the same letter are not significantly different at $\mathrm{p}<0.05$

Table 4: Genotypic stability parameters of 13 groundnut genotypes for kernel yield across three environments in northern Cameroon.

\begin{tabular}{|c|c|c|c|c|c|c|c|}
\hline Genotype & Code & bi & $\mathbf{W}_{\mathrm{i}}$ & $\sigma_{i}^{2}$ & IPCA1 & IPCA2 & ASV \\
\hline Campana & 3 & $0.34(4)$ & $59909.0(8)$ & $0.82(8)$ & -1.08 & 0.07 & $1.31(5)$ \\
\hline Dourou & 4 & $0.29(3)$ & $49180.5(4)$ & $0.65(4)$ & -1.19 & 0.09 & $1.25(3)$ \\
\hline CGS 1272 & 6 & $1.06(7)$ & $59067.1(7)$ & $0.80(7)$ & 0.39 & -1.30 & $1.54(9)$ \\
\hline G-M-28-206 & 7 & $1.54(11)$ & $76412.2(10)$ & $1.08(10)$ & 1.10 & -0.92 & $1.56(10)$ \\
\hline ICGV86003 & 8 & $0.43(5)$ & $54036.3(5)$ & $0.72(5)$ & -1.05 & 0.51 & $1.33(6)$ \\
\hline NW-Red Esimbi & 11 & $-0.23(1)$ & $171567.6(11)$ & $2.60(11)$ & -2.00 & -0.27 & $1.73(11)$ \\
\hline Ouest-A2 & 12 & $0.68(6)$ & $19884.5(2)$ & $0.18(2)$ & -0.61 & 0.37 & $1.34(7)$ \\
\hline RMP 91 & 13 & $1.20(8)$ & $5568.5(1)^{1}$ & $0.05(1)$ & 0.28 & 0.27 & $1.01(2)$ \\
\hline
\end{tabular}

bi: Finlay and Wilkinson's regression coefficient; Wi: Wricke's ecovalence; $\sigma_{\mathrm{i}}{ }^{2}$ : Shukla's stability variance parameter;ASV: AMMI's stability value; IPCA : Interaction Principal Component Axis ; Numbers between parenthesis denote ranking order of varieties for each stability parameter. 


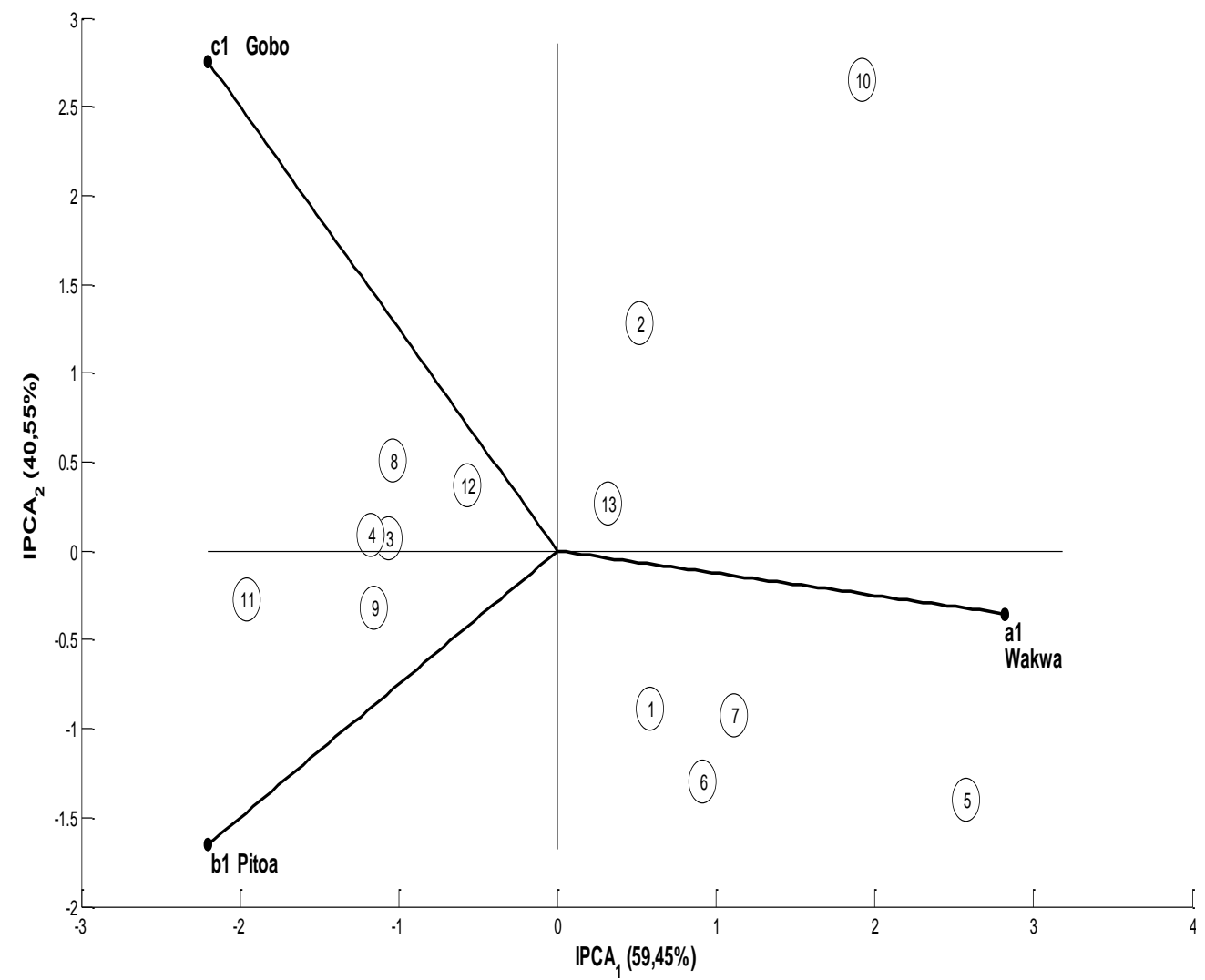

Fig. 1: AMMI biplot of IPCA1 against IPCA2 for kernel yield of 13 groundnut genotypes grown in three locations in northern Cameroon. a1=Wakwa; b1=Pitoa; c1=Gobo; 1=Ad-Mapienta; 2=Blanc; 3=Campana; 4=Dourou; 5=Gobo-55-437; 6=CGS 1272; 7=G-M-28-206; 8=CGV86003; 9=JL 28; 10=K1332-78; 11=NW-Red Esimbi; 12.Ouest-A2; 13=RMP 91.

\section{DISCUSSION}

Selection of specific crop genotypes in plant breeding is often preceded by multi-location testing in which the relative performance of the genotypes under study almost invariably changes from one environment to another [13]. When GEI is highly significant for a particular trait such as yield, no valid comparison could be made regarding the relative performance of genotypes over all environments [14]. In our study, significance of all sources of variation indicated differential behavior of tested genotypes, which was not consistent with different environments. A large sum of square for genotypes indicated diversity of tested lines, with large difference among genotypic means causing variation in the plant seed yields. However, the pronounced difference in yield and other attributes over locations is an indication that these characters are under both genetic and environmental effects [22]. The higher genotypic variation relative to environmental counterparts is consistent with the autogamous nature of groundnut which shows homozygosity at various loci [22]. The AMMI model also demonstrated the presence of GEI showing that certain varieties performed better than others and their yield potential differed from location to another. GEI was considered as a good indication of biotic and abiotic factors affecting crops production in the respective areas as previously reported $[14,23]$. Yields were influenced by varied eenvironmental factors like soil types, rainfall pattern and planting date which induce GEI $[4,23,25]$. A wide range of soils and climatic conditions are encountered in northern Cameroon [22]. Plant selection could be more effective if there is a consistency in yield of best selection over a wide range of environmental factors. The development of high yielding and well adapted varieties is the ultimate aim of plant breeders. However, attaining this goal is made complicated by high magnitude of GEI [15]. Significant interactions (variety $x$ location, variety $\times$ year, variety $x$ location $\times$ year) in groundnut for seed yield and yield components have been early reported by several studies $[4,7,8,10,11,24,25,26]$. The results obtained were in accordance with findings in Nigeria [26]. In contrast, large location effects and high magnitude of GEI were noted for pod yield in segregating populations of groundnut under semi-arid conditions at Niger [8].The variance component due to environment was also found to be the largest for groundnut yield by [8]. Elsewhere, the existence of genetic variation for number of pods per plant and seed weight was employed as the basis for improving yield due to the highly significant and positive association between kernel yield and these traits [22]. Seed yield in groundnut was highlighted to have significant and positive correlation with 100-seed weight and with the number of pods per plant $[4,9,22]$. The Gobo-55-437 and Blanc genotypes with the highest number of pods per plant, and Ad-Mapienta with higher seed weight could be included in breeding program for yield 
improvement. The values of adaptability parameter bi [6] showed that JL 28, and Dourou were relatively stable whereas K1332-78, Gobo-55-437, GM-28-206 and Blanc with bi>1are indicated in superior or higher yielding environments. Varieties JL 28, Dourou, Campana, NW-Red Esimbi, Ouest-A2 and ICGV86003 were considered to be adapted to lower yielding or unfavorable environments since their bi values were smaller than 1.0. Among the top five genotypes, Dourou and JL 28 were suitable for lower yielding environments.

According to the ASV ranking, genotypes JL 28, RMP 91 and Dourou had the lowest values, and therefore the most stable varieties, whereas K1332-78 and Gobo-55-437 were the most unstable.

In general, data obtained on stability showed that none of the tested genotypes could be considered as completely stable. Similar observation has been previously reported in groundnut $[4$, 7, 11, 28]. The ideal genotype should have the highest mean performance and be absolutely stable with zero GEI [14, 23]. The stability analysis showed among top-yielding cultivars, Durou appearing as a widely adapted material, while Gobo-55-437 and Blanc could be exploited as specifically adapted germplasm around Pitoa and Gobo. Dourou had combination of low GEI and highest kernel yield, making it the most suitable for cultivation across locations in northern Cameroon. Ouest-A2 and NW-Red Esimbi were identified as being average stable, but very poor in yield and may thus not be appealing either as a selection or for breeding new varieties.

Obviously, the procedures used in this study are not particularly contradictory in selection for the tested environments factors and could consequently be jointly used to explore GEI and stability analyses for genotype selection. In analysis of cultivar stability, [18] found significant correlation between the stability measures ASV, Wi, and $\sigma_{\mathrm{i}}{ }^{2}$, but noted that bi regression coefficient had limited association with other methods. Further, a genotype can be considered highly stable if all the important parameters of stability are satisfied [29, 30]. According to [31], the ASV was considered to be the most appropriate single method of describing the stability of genotypes. Multilocation trials should be repeated in time to distinguish between repeatable and non-repeatable GEI effects that have been recorded by earlier reports from various countries [28, 29, 30, 32].

In a biplot display, any genotypes or environments that fall almost on a horizontal line had similar interactions [20].The closer the point is to the biplot origin, the more stable is the genotype; the more distant, the greater the contribution to the interaction. Thus, RMP 91, Ouest- $\mathrm{A}_{2}$, Dourou and JL28 are considered as stable genotypes being closest to biplot origin. Genotypes or environments close to each other have the same pattern as to the GEI [20]. There were considerable differences between environments. Wakwa in the Adamawa region appeared as the most unfavourabe environment. Better yielding environments (Pitoa and Gobo) were well separated from Wakwa. As outlined by [33], specific adaptation may be desirable where greater differences between locations exist and genotype regionalization may be a necessity.

\section{CONCLUSION}

In the development and release of groundnut genotypes for cultivation, analysis of GEI is necessary to determine the stability of performance of the variety across environments. From this study, genotype Dourou could be recommended for wide cultivation across the areas of northern Cameroon, because of its higher and stable yield. Of the thirteen genotypes tested, Gobo-55437 and the introduced line Blanc could also be used in cultivation or in breeding for improved kernel yieldin their favorable environments around Pitoa and Gobo. These results could be used by breeding programs, as well as national institutions committed to testing or recommending groundnut varieties for more effective selection and targeting of materials.

\section{ACKNOWLEDGEMENTS}

The lead author is immensely grateful to the funding of the International Foundation for Science (IFS grant C5599-1). The authors acknowledged with thanks the staff of the SODECOTON and IRAD for kindly providing seeds sample used in this study. They also thankful to Pr Ukai Yasuo of the University of Tokyo for providing the microcomputer program GEST 98 for data analysis.

\section{REFERENCES}

1. Janila P, Nigam SN, Pandey MK, Nagesh P, Varshney RK. Groundnut improvement: use of genetic and genomic tools. Frontiers in Plant Science. 2013 February 25; 4a23. doi:10.3389/fpls.2013. 00023.

2. AGRI-STAT. Annual statistics of agriculture, number 17. MINADER, DESA; Yaoundé, Cameroon, 2012.

3. Hamasselbe A. La revalorisation de la filière arachide dans la zone soudano sahélienne du Nord Cameroun. Tropicultura. 2008; 26(4):200-205.

4. Mekontchou T, Ngueguim M, Fobasso M. Stability analysis for yield and yield components of selected peanut breeding lines (Arachis hypogaea L.) in the North province of Cameroon. Tropicultura. 2006; 24(2): 90-94.

5. Hardwick RC, Wood JT. Regression methods for studying genotypeenvironment interactions. Heredity. 1972; 28:209-222.

6. Finlay KW, Wilkinson GN. The analysis of adaptation in a plant breeding program. Austr. J. Agric. Res. 1963; 14:742-754.

7. Punto NG, Lantinan RM. Genotype $x$ Environment interaction for yield in field legumes: I. Peanut, Arachis hypogaea L. Phillipp. J. Crop Sci. 1982; 7(2): 94-100.

8. Ntare BR, Williams JH. Heritability and genotype $\mathrm{x}$ environment interaction for yield and components of a yield model in segregating populations of groundnut under semi-arid conditions. Afr. Crop Sci. J.1998; 6(2): 119-127.doi:10.4314acsj.v6i2.27807.

9. Badigannavar, AM, Kale DM, Murty GSS. Genetic base and diversity in peanut genotypes. Plant Breeding. 2002;121:348-353.

10. Iwo GA, Idowu AA, Olorunji PE. Genotype $\mathrm{x}$ environment interaction for pod yield of groundnut varieties in southern Guinea savannah of Nigeria. Nigerian Journal of Genetics. 2002.16 \& 17: 48-51.

11. Mothilal A, Vindhiya VP, Manivannan N. Genotype $x$ environment for kernel yield in groundnut (Arachis hypogaea L.). Electronic J. Plant Breeding. 2010: 1(5): 1306-1308. 
12. Wricke G. Uebereine method zurerfassung der oekologischenstreubreite in feldversuchen. Z. Pfanzenzucht. 1962; 47: 92-96.

13. Shukla GK. Some statistical aspects of partitioning genotypeenvironmental components of variability. Heredity. 1972; 29: 237 245.

14. Okuno C, Kikuchi F, Kumagai K, Shiyomi M, Tabuchi H. Evaluation of varietal performance in several environments. Bull. Natl. Inst. Agric.1971; 18: 93-147.

15. Zobel RW, Wright MJ, Gauch HG. Statistical analysis of a yield trial. Agronomy Journal. 1988; 80:388-393.

16. Gauch HG. Statistical analysis of regional yield trials: AMMI analysis of factorial designs. Crop Sci. 1992; 46:1488-14500.

17. Noubissié TJB, Dolinassou S, Njintang YN, Nguimbou MR, Zaiya ZA. Genetic variability and heritability estimates of some properties of groundnut (Arachis hypogaea L.) kernels. Int. J. Bios.2012;2(1), 25-35.

18. Purchasse JL. Parametric analysis to describe $\mathrm{G} \times \mathrm{E}$ interaction and yield stability in winter wheat. Ph.D thesis, Faculty of agriculture, University of the Free State, Bloemfontein, South Africa, 1997.

19. Gollob HF. A statistical model which combines features of factor analytic and analysis of variance techniques. Psychometrika.1968; 33:73-115.

20. Crossa J, Fox PN, Preiffer WH, Rajaram S, Gauch HG. AMMI adjustment for statistical analysis of an international wheat yield trial. Theor. Appl. Genet. 1991;81: 27-37.

21. Ukai,Y. GEST. Programs for the analysis of genotype $\mathrm{x}$ environment interaction. Migimomi, Tsuchiura, Ibaraki 300-0837, Japan, 2000.

22. Nath UK, Alam MS. Genetic variability, heritability and genetic advance of yield and related traits in groundnut (Arachis hypogaea L.). J. Biol. Sci. 2002; 2: 762-764.

23. Ikeogu UN, Nwofia GE. Yield parameters and stability of soybean (Glycine max L. Merill) as influenced by phosphorus fertilizer rates in two ultisols. Int. J. Adv. Res. Agric. 2013; 1(2): 20-28.

24. Bucheyeki TL, Shenkalwa EM, Mapunda TX, Matata LW. On-farm evaluation of promising groundnut varieties for adaptation and adoption in Tanzania. Afr. J. Agric. Res.2008;3(8):531-536.

25. Khan A, Bano A, Bakht J, Khan SA, Malik NJ, Naz I. Response of exotic groundnut genotypes to environmental diversities at higher altitude of northern Pakistan. Sarhad J. Agric. 2009; 25(4): 545-550.
26. Makinde SCO, Ariyo OJ. Analysis of genotype $\mathrm{x}$ environment interaction of groundnut (Arachis hypogaea L.). Malays. J. Appl. Biol. 2010; 40(2):19-26.

27. Makinde SCO, Ariyo OJ. Multivariate analysis of genetic divergence in twenty two genotypes of groundnut (Arachis hypogaea L.). J. Plant Breed. Crop Sci. 2010; 2(7): 192-204.

28. Viswanathan PL, Manivannan, N, Murugan E, Mohanasundaram K. Phenotypic stability analysis in groundnut (Arachis hypogaea L.) Agric. Sci. Digest. 2001; 21(3): 164-166.

29. Fekadu G, Mohammed H,Alemaw G. Genotype x environment interactions and stability of soybean for grain yield and nutrition quality.Afr. Crop Sci. J. 2009;17 (2): 87-89.

30. Nawaz, SM, Nawaz N, Yusuf M, Khan MA, Mirza MY, Mohmand AS, Sher MA, Masood MA. Stability performance for pod yield in groundnut. Pak. J. Agric. Res. 2009; 22(3-4): 116- 119.

31. Naroni Rad MR, Abdul Kadir M, Rafu MY, Jafar HZE, Naghavi MR, Farzaneh A. Genotype x Environment interaction by AMMI and GGE biplot analysis in three consecutive generations of wheat (Triticum aestivum) under normal and drought stress conditions. Austr. J. Crop Sci. 2013; 7(7): 956-961.

32. Makinde SCO, Ariyo OJ, Akinbowale RI. Assessment of groundnut performance in different environments using additive main effects and multiplicative interaction (AMMI) model. Can. J. Plant Breed.2013; 1(2): 60-65.

33. Gunasekera CP, Martin LD, Siddique KHM, Walson GH. Genotype by environment interactions of Indian mustard (Brassica juncea L.) and canola (B. napus L.) in Mediterranean-type environments.1. Crop growth and seed yield. Europ. J. Agronomy 2006; 25: 1-12

How to cite this article:

Dolinassou S, Noubissié TJB, Djiranta AK and Njintang YN. Genotype $\times$ environment interaction and kernel yield-stability of groundnut (Arachis hypogaea L.) in Northern Cameroon. J App Biol Biotech. 2016; 4 (01): 001-007. DOI: 10.7324/JABB.2016.40101 